\title{
Classroom Instructional-Based Technology as Predictor of Quality Services Delivery for Academic Staff in Delta State University
}

\author{
Felix Omemu ${ }^{1(\bowtie)}$ and Ajuebon A. Veronic ${ }^{2}$ \\ ${ }^{1}$ Educational Foundations, Faculty of Education, Niger Delta University, Wilberforce Island, Nigeria \\ ${ }^{2}$ Dick and Alice International School, Nigeria \\ Felixomemu43@gmail. Com
}

\section{ABSTRACT}

The study investigated the predictive powers of classroom instructional-based technology on quality services delivery of academic staff in Delta State University. Three research questions and three hypotheses guided the study. The study adopted a correlation research design. The population was 861 lecturers in the Delta state university with a sample size of 430 drawn through proportionate stratified method representing 50\% of the population. A 30-item Classroom Instructional-Based Technology Scale (CIBTS) and 15-item Quality Services Delivery Scale (QSDS) were used for data collection. The scales were validated by three experts in Information and Communication Units. The internal consistency reliability coefficients of 0.78 and 0.81 were computed for CIBTS and QSDS through Cronbach alpha. Liner regression was used to answer the research questions while t-test associated with linear regression was used to test the null hypotheses at 0.05 level of significance level. It was found that classroom instructional-based technology can significantly predict quality services delivery of academic staff in Delta State Universities. More so, classroom instructional-based technology with the use of interactive whiteboard, video conferencing and virtual field trip can independently predict quality instructional delivery. It was recommended among others that the university authority should ensure that the lecture halls and classrooms in the university are equipped with functional interactive whiteboards. The academic staff should be availed the opportunity for capacity development and enhancement on the use of communication technologies such as interactive whiteboard. The university authorities as well as the heads of departments and deans of faculties should make available computers, projectors, internet connectivity, power supply, printers and flash drive that can encourage video conferencing. The academic staff should be very proactive in the determination of sites that can provide them needed information and learning through the virtual field trip platform.

Keywords: classroom instructional-based technology, interactive whiteboard, video conferencing, virtual field trip, quality services delivery

Cite this article as: Omemu, F., \& Veronic, A. A. (2021). Classroom Instructional-Based Technology as Predictor of Quality Services Delivery for Academic Staff in Delta State University. Journal of e-learning Research, 1(1), 23-33. https://doi.org/10.33422/jelr.v1i1.51

\section{Introduction}

Classroom is an organized setting where instruction and learning can take place. Instruction in the classroom is effective when it is achieving the desired goals and objectives. The classroom instruction has to do with the teaching and learning activities that go on. Instruction is adjudged to have quality when it is in line with expectations. Quality instruction or service delivery in the school is one that can change students' perception of life and how 
they can effectively use the acquired knowledge in solving issues around them. Quality instruction is that which is received under a qualified teacher with good teaching behavior (Educational International, 2011). More so, quality instructional delivery is one that met the instructional objectives. The strong indicators of quality teaching as highlighted by DarlingHammond (2011) include that it:

- Engages the students in an active lesson

- Creates room for intellectualization

- Uses different teaching approaches

- Assesses students learning development

- Continuously making activities to be in line with students' needs

- Creates functional supports and scaffolds

- Provides clear standards, regular feedback and condition for mastery learning

- Provides measures for effective and high defined classroom management and control

This goes on to explain the fact that quality instruction brings about quality learning to a reasonable extent. Without quality instructional services, the reputations of the students and the school will be to a very lower level (Ibiam, 2018). Poor quality instructional services have been found to be one of the major causes of students' underachievement in their educational pursuit (Uzochukwu, 2019), ill behaviours (Onukwufor, 2018) and lack competitive spirit among the students (Bolaji, 2019). It has been reported that instructional delivery has prominent roles to play in effective instructional delivery (Akarauwa, 2018). Teachers who use poor and sub-standard instructional delivery frequently end up not achieving the instructional objectives in specific terms (Peters, 2017). There is a serious pointer towards the frequent use of modern classroom in order to achieve effective instructional delivery (Azubuike, 2016). Classroom instruction can be carried out through different methods. It could be through the convention old traditional method of teaching or through technology based. Over the years, classroom instruction has taken the part of traditional or conventional method. The world has become a global village through the functionality of technology. The Western world has moved away from constructivism to connectivism in their educational sectors. Schools in Nigeria especially in Delta State can key into this trend of development if quality must be assured in the schools through the use of technology based instruction.

Technology based instruction is the use of technological appliances in the discharge of teaching responsibility. Technology based instruction connotes the use of digital tools in the teaching process. It is the use of technology and technology know-how to dispense instructions. Technology based instruction is an approach deemed suitable in the transformation of educational sector (US Department of Education, n.d). Technology based education has the potentials to transform teaching by ushering in a various new model of electronic teaching. With technology education, teachers can improve on their professional content, resources, and systems to help students acquire the right content and skills (US Department of Education, n.d).Technology base education can expose the teachers to open educational resources and other technologies (US Department of Education, n.d). Technology education is proposed to be effective in enhancing educational productivity as well as to increase the rate of learning; reduces costs associated with instructional materials or program delivery; and better utilization of instructional time (US Department of Education, n.d). 
Technology education can be carried out through interactive whiteboard, projectors, video conferencing, virtual field trip and computer networking (US Department of Education, n.d). Interactive whiteboardis a hardware device that is operated electronically but has the same similarity with a whiteboard. It has the capacity to transmit series of information sent into it to different computers at a very fast pace. People use interactive whiteboards to share messages, present information, and engage in collaborative brainstorming and idea development as well as to connect to the Internet and instantly digitize tasks and operations (WhatIs.com, 2020). The interactive whiteboard is a make-up of computer, a data projector and an electronic screen (Wood \&Ashfield, 2008). Interactive whiteboard is effective in the achievement of educational goal because it consists of written text, sound, pictures, software packages, CD ROM, video clips, websites and internet (Ekhalm, 2002; Glover \& Miller, 2002). Teachers who are technologically inclined can make use of interactive whiteboard in the actualization of the teaching processes (Morgan, 2010). It is simply a whiteboard that displays information logged in through computer. Interactive whiteboard enables the students to have direct interaction with the software teaching materials. Interactive whiteboards create room for the students to interact with the learning material. Interactive whiteboards integrate various learning styles into one experience (Platinum Copier Solutions, 2017). Interactive whiteboard enhances students 'attention, comprehension, performance, retention and increase in learning (Platinum Copier Solutions, 2017). To this end, students can learn by what they see, hear as well as having physical interaction with the teaching resources. Interactive whiteboard usage makes the teachers to acquire new, innovative ways to teach the same subject material. Interactive whiteboard has been reported to help students learn better and remember more (Platinum Copier Solutions, 2017). Interactive whiteboard is synonymous with video conferencing in that they are both electronically operated. Video conference is a platform that allows knowledge sharing through sound and vision by people within and in other locations.

Video conferencing is suitable for the classroom because it enables educators to bring the world to their lesson delivery, helping to create inspiring, interconnected learning experiences (Promethean, 2016). Reportedly, more educators are pulling video conferencing into their classrooms. In addition to the many colleges around the world that use classroom video conferencing (Horton, 2020). It is evidential that approximately 25 percent of public schools in the United States make up their educational system with video conferencing education (Greenberg, 2006). Video conferencing reduces the cost of tuition and expands learning opportunities for people everywhere, even those in rural or remote areas (Stem Audio, 2020). Classroom video conferencing when properly applied can enhance learning (Horton, 2020). Video conferencing meets the need of students irrespective of their locations (Horton, 2020). Video conferencing share the same attribute with virtual field trip.

Virtual field trip is a classroom organized virtual outing to the experiential world or areas of interest without physically visiting the site. This platform enables the students to go places of event without leaving the classroom (Discovery. Education, 2020). The virtual field trip portrays the same quality of the conventional field trip on that there is no physical visitation but online of access to sites of interest in the virtual field trip just as it is done in the conventional. The use of virtual environments according to National Research Council (2002) as cited in Cox (2012) has the ability to make learners: 
- Think critically and logically about scientific ideas and compare them with real-life conditions.

- Critically evaluate and communicate scientific ideas.

- Formulate scientific explanations from evidence.

- Use appropriate tools to gather, analyze, and interpret data. (p. 19)

The virtual field trip websites can make new, complex, and controversial information are readily available (Cox, 2012). This platform can also allow students to travel in virtual space, not just in our world but all over the universe (Cox, 2012). This technological approach to field trip can make students to cover a wide range of instructional assimilation at very short period of time as they are obliged to be exposed to different virtual field activities without necessarily making physical movement to the destination in question. Virtual field trip requires great deal of computer networking and internet connectivity. Globally, it has been reported that classroom-based instruction is very effective in academic activities in universities (Adamu, 2018). In the Nigerian context, few studies have shown the importance of classroom-based technology in quality educational delivery in secondary schools (Chukwuma, 2017; Uwaoma, 2018). It has not been properly documented the prediction of classroom instructional-based technology on quality service delivery of academic staff of Universities in Delta State. This gap necessitated this study that aimed at investigating the predictive powers of classroom instructional-based technology on quality services delivery of academic staff of Universities in Delta State

\subsection{Statement of the Problem}

Teachers are obligated to ensure that they discharge quality and quantity instructions in their various areas of specializations. Studies have reported that the quality of instructional delivery in schools especially in the universities and other level of education are increasingly on the decrease. This is irrespective of teachers' qualification, students' readiness, teachers' experience and capacity building programmes such as seminars, workshops and conferences made available for the teachers. So many students are losing interest in educational pursuit due to lack of quality in the teaching methods. This ugly scenario seems to have prompted poor teaching quality which may have resulted to underperformance among the students. Lack of quality educational delivery methods cannot add values in our educational system and as such, the achievement of goals and objectives of the school would be greatly hampered. Therefore, the research is bothered and investigated to ascertain the predictive powers of classroom instructional-based technology on quality services delivery of academic staff of Universities in Delta State.

\subsection{Aim and Objectives}

The study aimed at investigating the predictive powers of classroom instructional-based technology on quality services delivery of academic staff in Delta State University. Specifically, the study sought to:

1. Find out the extent electronic whiteboard can predict quality service delivery for academic staff in Delta State University. 
2. Examine that extent Video conferencing classroom technology can predict quality service delivery for academic staff in Delta State University.

3. Determine the extent Virtual field trip can predict quality service delivery for academic staff in Delta State University.

\subsection{Research Questions}

The following research questions were answered to guide the study.

1. To what extent does electronic whiteboard predict quality service delivery for academic staff in Delta State University?

2. To what extent does Video conferencing classroom technology predict quality service delivery for academic staff in Delta State University?

3. What is the extent of prediction of Virtual field trip on quality service delivery for academic staff in Delta State University?

\subsection{Hypotheses}

The following hypotheses were tested at 0.05 level of significance.

1. Electronic whiteboard does not significantly predict quality service delivery on academic staff in Delta State University.

2. Video conferencing classroom technology does significantly predict quality service delivery on academic staff in Delta State University.

3. Virtual field trip does significantly predict quality service delivery on academic staff in Delta State University.

\section{Methodology}

The study adopted a correlation research design. The population was 861 lecturers of the Delta state universities with a sample size of 430 drawn through proportionate stratified method representing $50 \%$ of the population. A 30-item Classroom Instructional-Based Technology Scale (CIBTS) and 15-item Quality Services Delivery Scale (QSDS) were used for data collection. The first self-report CIBTS has two sections. The first section contained demographic information of the respondents such as school name, designation, qualification, school type, gender, age, computer experience respectively. The second section has three clusters of Electronic Whiteboard, Video Conferencing Classroom Technology and Virtual Field Trip with 10-items each. The measure CIBTS was designed in line with the four points response options of Very High Extent (VHE), High Extent (HE), Low Extent (LE) and Very Low Extent (VLE) with minimum and maximum scores of 30 and 120 respectively.

The second measure QSDS also contained the same demographic information as it is in the CIBTS. QSDS was designed to have four response options of High Extent (VHE), High Extent (HE), Low Extent (LE) and Very Low Extent (VLE) with minimum and maximum scores of 15 and 60 respectively. The scales were validated by three experts in Information and Communication Units. The internal consistency reliability coefficients of 0.78 and 0.81 were computed for CIBTS and QSDS through Cronbach alpha. Liner regression was used to answer the research questions while t-test associated with linear regression was used to test the null hypotheses at 0.05 level of significance level. 


\section{Results}

Research Question 1: To what extent does electronic whiteboard predict quality service delivery of academic staff in Delta State University?

Table 1.

Linear Regression on the Extent of Prediction of Electronic Whiteboard on Quality Service Delivery

\begin{tabular}{ccccc}
\hline \multicolumn{5}{c}{ Model Summary } \\
\hline Model & $\mathrm{R}$ & R Square & Adjusted R Square & Decision \\
\hline 1 & $.892^{\text {a }}$ & .795 & .794 & High Extent \\
\hline Legends: Very Low Extent (0-25), Low Extent (25.1-50), High Extent (50.1-75) Very High Extent (75.1-100)
\end{tabular}

The coefficient of determinism $\mathrm{R}^{2}$ (.795) showed the extent of prediction. This revealed that electronic whiteboard predict quality service delivery of academic staff in Delta State University to a high extent. This implied that electronic whiteboard accounted for $79.5 \%$ $(.795 * 100)$ quality service delivery while the remaining $20.5 \%$ were accounted by other variables not used in this study.

Research question 2: To what extent does Video conferencing classroom technology can predict quality service delivery of academic staff in Delta State University?

Table 2.

Linear Regression on the Extent of Prediction of Video Conferencing Classroom Technology on Quality Service Delivery

\begin{tabular}{|c|c|c|c|c|}
\hline \multicolumn{5}{|c|}{ Model Summary } \\
\hline Model & $\mathrm{R}$ & R Square & Adjusted R Square & Std. Error of the Estimate \\
\hline 1 & $.812^{\mathrm{a}}$ & .659 & .658 & 2.83801 \\
\hline
\end{tabular}

The coefficient of determinism $\mathrm{R}^{2}$ (.659) showed the extent of prediction. This revealed that Video conferencing classroom technology can predict quality service delivery of academic staff in Delta State University to a high extent. This implied that Video conferencing classroom technology accounted for $65.9 \%(.659 * 100)$ quality service delivery while the remaining $34.1 \%$ were accounted by other variables not used in this study.

Research question 3: What is the extent of prediction of Virtual field trip on quality service delivery of academic staff of Delta State University?

Table 3.

Linear Regression on the Extent of Prediction of Virtual Field Trip on Quality Service Delivery

\begin{tabular}{|c|c|c|c|c|}
\hline \multicolumn{5}{|c|}{ Model Summary } \\
\hline Model & $\mathrm{R}$ & R Square & Adjusted R Square & Std. Error of the Estimate \\
\hline 1 & $.883^{\mathrm{a}}$ & .780 & .779 & 2.28131 \\
\hline
\end{tabular}


The coefficient of determinism $\mathrm{R}^{2}$ (.780) showed the extent of prediction. This revealed that prediction of Virtual field trip on quality service delivery on academic staff of Delta State University to a high extent. This implied that Virtual field trip accounted for $78.0 \%$ $(.780 * 100)$ quality service delivery while the remaining $22.0 \%$ were accounted by other variables not used in this study.

Hypothesis 1: Electronic whiteboard does not significantly predict quality service delivery on academic staff in Delta State University

Table 4.

T-Test Associated with Linear Regression on the Prediction of Whiteboard on Quality Service Delivery

\begin{tabular}{llccccc}
\hline \multicolumn{7}{c}{ Coefficients $^{\mathbf{a}}$} \\
\hline Model & & \multicolumn{2}{c}{ Unstandardized Coefficients } & Standardized Coefficients & \multirow{2}{*}{ T } & Sig. \\
\cline { 3 - 8 } & & $\mathrm{B}$ & Std. Error & Beta & & \\
\cline { 3 - 8 } 1 & (Constant) & 4.549 & 1.044 & & 4.357 & .000 \\
& Whiteboard & .882 & .030 & .892 & 29.693 & .000 \\
\hline
\end{tabular}

Table 4 revealed that the t-test associated with linear regression is 29.693 , probability value is 00 and alpha level is .05 respectively. Since the probability value of .00 is less than the alpha level of .05 , the null hypothesis is rejected. Therefore, Electronic whiteboard significantly predicted quality service delivery on academic staff in Delta State University.

Hypothesis 2: Video conferencing classroom technology does significantly predict quality service delivery on academic staff in Delta State University.

Table 5.

T-Test Associated with Linear Regression on the Prediction of Video Conferencing Technology on Quality Service Delivery.

\begin{tabular}{|c|c|c|c|c|c|c|}
\hline \multicolumn{7}{|c|}{ Coefficients $^{\mathrm{a}}$} \\
\hline & \multicolumn{2}{|c|}{ Unstandardized Coefficients } & \multirow{2}{*}{$\begin{array}{c}\text { Standardized Coefficients } \\
\text { Beta }\end{array}$} & \multirow{2}{*}{$\mathrm{T}$} & \multirow{2}{*}{ Sig. } \\
\hline & & B & Std. Error & & & \\
\hline \multirow[b]{2}{*}{1} & $\begin{array}{l}\text { Model } \\
\text { (Constant) }\end{array}$ & 6.541 & 1.382 & & 4.733 & .000 \\
\hline & $\begin{array}{l}\text { Video conferencing } \\
\text { technology }\end{array}$ & .830 & .040 & .812 & 20.965 & .000 \\
\hline
\end{tabular}

Table 5 revealed that the t-test associated with linear regression is 20.965 , probability value is 00 and alpha level is .05 respectively. Since the probability value of .00 is less than the alpha level of .05, the null hypothesis is rejected. Therefore, Video conferencing classroom technology significantly predicted quality service delivery on academic staffof Delta State University.

Hypothesis 3: Virtual field trip does significantly predict quality service delivery of academic staff of Delta State University 
Table 6.

T-Test Associated with Linear Regression on the Prediction of Virtual Field Trip on Quality Service

Delivery

\begin{tabular}{|c|c|c|c|c|c|}
\hline \multicolumn{6}{|c|}{ Coefficients $^{\mathbf{a}}$} \\
\hline \multirow[t]{2}{*}{ Model } & Unstandar & Coefficients & Standardized Coefficients & & \\
\hline & B & Std. Error & Beta & t & Sig. \\
\hline (Constant) & 6.067 & 1.040 & & 5.835 & .000 \\
\hline Virtual field trip & .837 & .029 & .883 & 28.364 & .000 \\
\hline
\end{tabular}

Table 6 revealed that the t-test associated with linear regression is 28.364 , probability value is , 00 and alpha level is .05 respectively. Since the probability value of .00 is less than the alpha level of .05 , the null hypothesis is rejected. Therefore, Virtual field trip significantly predicted quality service delivery of academic staff of Delta State University.

\section{Discussion of Findings}

\subsection{Interactive Whiteboard and Quality Service Delivery}

The study revealed that interactive whiteboard significantly predicted quality services delivery to a high extent among academic staff of Delta State University. The outcome of this result may be attributed to the fact that Interactive whiteboard can be used to share messages, present information, and engage in collaborative brainstorming and idea development as well as to connect to the Internet and instantly digitize tasks and operations for effective service delivery (WhatIs.com, 2020). The interactive whiteboard is supports teaching to a very extent with its components of computer, a data projector and an electronic screen which makes teaching and learning enabled (Wood \&Ashfield, 2008). Still buttressing the finding of this study was the report that Interactive whiteboard is effective in the achievement of educational goal because it consists of written text, sound, pictures, software packages, CD ROM, video clips, websites and internet (Ekhalm, 2002; Glover \& Miller, 2002).

More so, teachers who are technologically inclined have been found to make use of interactive whiteboard in the actualization of the teaching processes (Morgan, 2010). Interactive whiteboard is very important to effective teaching because it enables the students to have direct interaction with the software teaching materials. In the same vein, Interactive whiteboards create room for the students to interact with the learning material. The most striking factor about Interactive whiteboards that makes it support effective service delivery is because it integrates various learning styles into one experience (Platinum Copier Solutions, 2017). In consonance to the finding of this study is the submission that Interactive whiteboard enhances students'attention, comprehension, performance, retention and increase in learning (Platinum Copier Solutions, 2017). To this end, students can learn by what they see, hear as well as having physical interaction with the teaching resources. Teachers record high service delivery because Interactive whiteboard helps students learn better and remember more (Platinum Copier Solutions, 2017). 


\subsection{Video Conferencing and Quality Service Delivery}

The study revealed that video conferencing significantly predicted quality services delivery to a high extent among academic staff of Delta State University. The predictive effectiveness of Video conference to quality service delivery is buttressed on the fact that it is a platform that allows knowledge sharing through sound and vision by people within and in other locations. The result is in tandem with the fact that Video conferencing is suitable for the classroom because it enables educators to bring the world to their lesson delivery, helping to create inspiring, interconnected learning experiences (Promethean, 2016). Agreeably, due the importance of video conferencing, many colleges around the world have resorted to using it for instructional delivery (Horton, 2020). The importance of video conferencing in service delivery has made approximately 25 percent of public schools in the United States to make up their educational system with video conferencing education (Greenberg, 2006). Quality educational delivery is assured because it enables the teachers to capture learners irrespective their locations (Stem Audio, 2020). It has been shown that proper application of Classroom video conferencing can enhance teaching (Horton, 2020). Video conferencing meets the need of students irrespective of their locations (Horton, 2020).

\subsection{Virtual Field Trip and Quality Service Delivery}

The study showed that virtual field trip can significantly predict quality service delivery among academic staff of Delta State University. There is great importance attached to field trip in the attainment of quality instructional delivery. This is very vital because students learn more when learning is concrete. Virtual field trip helps to concretize teaching and learning. This platform enables the students to go places of event without leaving the classroom (Discovery.Education, 2020). It enhances quality instruction because it saves time of traveling thereby increasing quality time of instructional delivery. The use of virtual environments according to National Research Council (2002) as cited in Cox (2012) have the ability to make learners think critically, logically about scientific ideas, critically evaluate and communicate scientific ideas, formulate scientific explanations from evidence and use appropriate tools to gather, analyze, and interpret data. Quality instruction is possible because virtual field trip websites can make new, complex, and controversial information readily available(Cox, 2012). This platform can also allow students to travel in virtual space, not just in our world but all over the universe (Cox, 2012). This technological approach to field trip can make students to cover a wide range of instructional assimilation at very short period of time as they are obliged to be exposed to different virtual field activities without necessarily making physical movement to the destination in question.

\section{Conclusion}

Based on the findings of this study, it was concluded that classroom instructional-based technology can significantly predict quality services delivery of academic staff of Delta State University. Specifically, it was concluded that classroom instructional-based technology with the use of interactive whiteboard, video conferencing and virtual field trip can independently predict quality instructional delivery among academic staff in Delta State University. 


\section{Recommendations}

Based on the findings of this study, it was recommended that:

1. The university authority should ensure the lecture halls and classrooms in the universities are equipped with functional interactive whiteboards. The academic staff should be availed the opportunity for capacity development and enhancement on the use of communication technologies such as interactive whiteboard.

2. The university authorities as well as the heads of departments and deans of faculties should make available computers, projectors, internet connectivity, power supply, printers and flash drive that can encourage video conferencing.

3. The academic staff should be very proactive in the determination of sites that can provide them needed information and learning through the virtual field trip platform.

- The topic; replace the first highlighted OF with FOR and the second OF with IN. Go through the abstract, objectives, research questions and conclusion to effect corrections.

- Space words where necessary

- Use indented paragraphing for better clarity

- Fill in missing words in methodology

- Recast sentence filled with " and"

\section{References}

Adamu, M.O. (2018). Classroom-based instruction and effective academic activities enhancement in schools. Journal of Educational and Developmental Studies, 1(1), 111-23.

Akarauwa, A.E. (2018). Management strategies in effective instructional delivery. Journal of Educational and Developmental Studies, 1(1), 32-49.

Azubuike, H.R. (2016). Impact of modern classroom in effective instructional delivery. Journal of School Management, 2(1), 78-90.

Bolaji, K.G. (2019). Influence of school instructional facilities on students' academic performance. Journal of School Management, 1(2), 43-53.

Chukwuma, F.V. (2017). Importance of classroom-based technology in quality educational delivery in secondary schools. Educational Journal of Human and Material Resource Development, 1(1), 136-58.

Cox, C. (2012). Literature based teaching in the content areas. Thousand Oaks, CA: SAGE Publications, Inc.

Darling-Hammond, L. (2011). Quality teaching: What is it and how can it be measured? Retrieved from https://edpolicy.stanford.edu/sites/default/files/events/materials/ldhscopeteacher-effectiveness.pdf

Discovery.Education (2020). Virtual field trip. Retrieved from https://www.discoveryeducationglobal .com/community/virtual-field-trips/

Educational International (2011). Quality teaching. Retrieved from https://www.ei-ie.org/en/detail _page/4657/quality-teaching

Ekhalm, L. (2002). The power of interactive whiteboards. School Library Media Activities Monthly, 18(8), 35-38.

Glover, D., \& Miller, S. (2002). Improving learning: Professional practice in secondary schools. Buckingham, UK: Open University Press. 
Greenberg, A. (2006). Taking the wraps off video conferencing in the U.S. classroom. Wainhouse Research from http://www.wrplatinum.com/Downloads/5912.asp

Horton, J. (2020). How classroom video conferencing works. Retrieved from https://people.howstu ffworks.com/classroom-video-conferencing.htm

Ibiam, O.P (2018). School facilities provision and quality instructional delivery.Journal of Educational and Developmental Studies, 1(1), 2-19.

Morgan, H. (2010). Teaching with the interactive whiteboard: An engaging way to provide instruction. University of Southern Mississippi, Spring 2010 focus on Elementary. Retrieved from https://files.eric.ed.gov/fulltext/ED577573.pdf

Onukwufor, K.M. (2018). Students' attitude towards facilities utilization in public schools. Journal of Educational and Developmental Studies, 1(1), 20-31.

Peters, J.F. (2017). Poor instructional aide utilization and teachers' classroom control. Educational Journal of Human and Material Resource Development, 1(1), 90-108.

Platinum Copier Solutions (2017). 7benefits if interactive whiteboards in the classroom. Retrieved from https://www.platinumcopiers.com/blog/aquos-board/7-benefits-of-interactive-whiteboards-inthe-classroom/\#: :text=Interactive\%20whiteboards\%20allow\%20children\%20to,be $\% 20$ played $\%$ 20by\%20entire\%20classrooms.

Promethean (2016). Why is video conferencing perfect for the classroom? Retrieved from https://resourced.prometheanworld.com/use-video-conferencing-classroom/

Stem Audio (2020). How to design a classroom with video conferencing equipment for distance learning. Retrieved from https://www.stemaudio.com/setup-a-classroom-with-video-conferencingequipment/

US Department of Education (n.d).Use of technology in teaching and learning. Retrieved from https://www.ed.gov/oii-news/use-technology-teaching-and-learning

Uwaoma, I.S. (2018). Status of instructional facilities in Nigerian universities. Journal of Educational and Developmental Studies, 1(1), 267-81.

Uzochukwu, A.L. (2019). Poor quality instructional services and students' underachievement. Journal of School Management, 1(2), 12-21.

WhatIs.com (2020). Interactive whiteboard. Retrieved from https://www.whatis.techtarget.com/ definition/interactive-whiteboard

Wood, R., \&Ashfield, J. (2008). The use of whiteboard for creative teaching and learning in literacy and mathematics: A case study. British Journal of Educational Technology, 39 (1), 84-96. 